YEARBOOK

of ANTITRUST

and REGULATORY

STUDIES

www.yars.wz.uw.edu.pl
Peer-reviewed scientific periodical, focusing on legal and economic issues of antitrust and regulation. Creative Commons Attribution-No Derivative Works 3.0 Poland License.

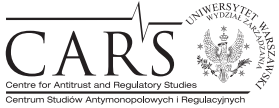

Centre for Antitrust and Regulatory Studies, University of Warsaw, Faculty of Management www.cars.wZ.uw.edu.pl

\title{
Legislative and Jurisprudential Developments in the Energy Sector in 2011
}

\author{
by
}

Filip Elżanowski*

\section{CONTENTS}

I. Introduction

II. Amendments to the Energy Law Act

1. Act on the Preparation and Implementation of Nuclear Facility Investment Projects and Related Facility Projects of 29 June 2011

2. Amendment Act to the Energy Law Act and to Some Other Acts of 1 August 2011

3. Amendment Act to the Crude Oil, Oil Products, and Natural Gas Reserve Act and on the Rules of Procedure in Situations of Threat to National Energy Security and Crude Oil Market Disruptions and on Amendments to Some Other Acts of 16 September 2011

III. Jurisprudence

1. Judgment of the Supreme Court of 6 October 2011 (Ref. No. III SK 18/11)

2. Judgment of the Supreme Court of 30 September 2011 (Ref. No. III SK 10/11)

3. Judgment of the Court of Appeals in Warsaw of 28 September 2011 (Ref. No. VI Aca 139/11)

4. Judgment of the Supreme Administrative Court in Warsaw of 23 September 2011 (Ref. No. II OSK 667/11)

5. Judgment of the Supreme Court of 12 April 2011 (File Ref. No. III SK 42/10)

6. Judgment of the Supreme Court of 12 April 2011 (Ref. No. III SK 46/10)

7. Judgment of the Court of Appeals in Warsaw of 17 March 2011 (Ref. No. VI ACa 1027/10)

IV. Summary

* Dr. Filip Elżanowski, Faculty of Law and Administration, University of Warsaw; advocate. 


\section{Introduction}

The year 2011 brought about fundamental changes to the legal framework affecting energy markets in Poland. The most important of these changes concerned rules on obligatory public trading of electric energy (so-called, exchange obligation) and the implementation of Nuclear Facilities Projects and Obligatory Natural Gas Reserve System Projects.

This publication contains a detail review of legal amendments passed in 2011 covering:

1) The Act on the Preparation and Implementation of Nuclear Facility Investment Projects and Related Facility Projects of 29 June $2011^{1}$ (in Polish: Ustawa o przygotowaniu i realizacji inwestycji $w$ zakresie obiektów energetyki jądrowej oraz inwestycji towarzyszacych; hereafter, Nuclear Project Investment Act);

2) The Amendment Act to the Energy Law Act and to Some Other Acts of 19 August 20112;

3) The Amendment Act to the Crude Oil, Oil Products, and Natural Gas Reserve Act and on the Rules of Procedure in Situations of Threat to National Energy Security and Crude Oil Market Disruptions and on the Amendments to Some Other Acts of 16 September $2011^{3}$ (in Polish: Ustawa z dnia 16 września 2011 r. o zmianie ustawy o zapasach ropy naftowej, produktów naftowych i gazu ziemnego oraz zasadach postępowania w sytuacjach zagrożenia bezpieczeństwa paliwowego państwa $i$ zaktóceń na rynku naftowym oraz o zmianie niektórych innych ustaw; hereafter, the Amendment Act to the Energy Security Act).

Article 1.18 of the Amendment Act to the Energy Law Act and on Amendments to Some Other Acts of 8 January $2010^{4}$, that came into force on 1 January 2011 (containing rules under which the Agricultural Biogas Production Support System was established), is not covered here since it had been already discussed in the 2010 Review.

Looking at the 2011 amendments to the Energy Law Act dated 10 April 19975 (in Polish: Prawo Energetyczne; hereafter, PE), it is first and foremost necessary to pay attention to the Amendment Act to Energy Law Act and to Some Other Acts of 19 August $2011^{6}$. This Act was originally meant to

\footnotetext{
1 Journal of Laws 2011 No. 135, item 789.

2 Journal of Laws 2011 No. 205, item 1208.

3 Journal of Laws 2011 No. 234, item 1392.

4 Journal of Laws 2010 No. 21, item 104.

5 Consolidated version: Journal of Laws 2006 No. 89, item 625, as amended.

6 Journal of Laws 2011 No. 205, item 1208.
} 
be a mere 'punctuation error correction amendment' (its aim was to insert a missing comma into Article 49a(2) of the Energy Law Act the lack of which made the proper application of this provision impossible). During the preparation process, the content of the Act was, nevertheless, greatly expanded. As a result, many new solutions were introduced into the 1997 Energy Law Act by way of this Amendment Act. The Energy Law Act was also subject to other changes resulting from legal amendments or new legislative acts meant to regulate the broadly defined Energy Sector that correlated indirectly with the provisions of the Energy Law Act. Changes that occurred on their basis are presented according to the order resulting from the layout of a given enactment.

Presented in this publication also is a review of key judgments (Judgments of the Supreme Court, Appeals Court in Warsaw, and Supreme Administrative Court) passed in 2011 under the rules of the Energy Law Act.

\section{Amendments to the Energy Law Act}

\section{Act on the Preparation and Implementation of Nuclear Facility Investment Projects and Related Facility Projects of 29 June 2011}

The Energy Law Act has been amended by a new legislative act of 2011 concerning nuclear energy - the Act on the Preparation and Implementation of Nuclear Facility Investment Projects and Related Facility Projects of 29 June 2011 - the Nuclear Project Investment Act.

Besides the amended Atomic Law Act ${ }^{7}$, the Nuclear Projects Investment Act is the key legislative act concerning the operation of nuclear facilities in Poland. In particular, it places special emphasis on the normalization of the investment process concerning nuclear facilities and those related to them. Its main objective is to establish a clear and stable legal framework for the investment process as a whole with respect to projects related to the construction of nuclear facilities in Poland in order for effective operations to be carried out in this area.

The changes made by the Nuclear Project Investment Act to the Energy Law Act cover, first and foremost, the necessity to take account of the specific nature of the investment process related to nuclear power plant construction. This change is reflected in the Investor's right to act upon a Nuclear Facility Construction Project Localization Decision rather than a planning permission.

\footnotetext{
7 Journal of Laws 2012 item 264.
} 
Moreover, the Transmission System Operator is now obliged to include nuclear safety and radiological protection requirements into the criteria for supplying power of electricity production units if they have the form of nuclear power plants.

The Nuclear Project Investment Act has amended the following provisions of the Energy Law Act: Article 1(3)(2), Article 7(8d), Article 9g(6)(5), and Article 33(1)(5).

The first amendment was meant to update the rule (e.g. Article 1(3) PE) which precludes the applicability of the Energy Law Act in matters regulated by the Atomic Law Act of 29 November 20008; the former version of the Energy Law Act referred in this case to the already invalid Atomic Law Act of 10 April $1986^{9}$.

The Nuclear Project Investment Act affected also the requirements to be fulfilled by applications for the issue of a statement of conditions under which connection to the grid can be made (e.g. Article 7(8d) PE). Apart from existing requirements concerning the appendices to applications for such statement, an entity applying for the connection of a power source to the grid of rated voltage higher than $1 \mathrm{kV}$ (local plan extract or if no such plan exists, a planning permission for the real property specified in a given application) shall also submit a Nuclear Facility Construction Project Localization Decision issued according to the Nuclear Project Investment Act.

Also expanded has been the Catalogue of Requirements on the content of grid traffic and the operation manual prepared by the Transmission System Operator (e.g. Article $9 g(6)(5) \mathrm{PE})$. It now includes the "criteria for supplying the power of electric energy production units where in a case of nuclear power plants, nuclear safety and radiological protection requirements - set forth in the Atomic Law Act of 29 November 2000 - and the criteria for administration of gas system connections or of power system connections shall be taken into account'.

Since the provisions of the Nuclear Project Investment Act have introduced a new legal institution in the form of a Nuclear Facility Construction Project Localization Decision, the requirements applicable to entities applying for a concession to the President of the Energy Regulatory Office (hereafter, URE President) have changed accordingly. Apart from current requirements set forth in Article 33(1) PE, the requirement to obtain a Nuclear Facility Construction Project Localization Decision by an applicant has been added.

\footnotetext{
8 Consolidated text: Journal of Laws 2007 No. 42, item 276, as amended.

9 Journal of Laws 1986 No. 12 of 1986, item 70, as amended.
} 


\section{Amendment Act to Energy Law Act and to Some Other Acts of 19 August 2011}

The most extensive changes to the Energy Law Act made in 2011 derive from the Amendment Act to Energy Law Act and to Some Other Acts dated 19 August 2011. Their aim was to insert a missing comma in the provisions concerning obligatory trading of electricity on exchange by producers that take advantage of financial assistance under the Long-Term Contract Termination $\operatorname{Act}^{10}$. This apparently benign omission has raised the question whether the public trading duty can or cannot be fulfilled by way of commodity exchange or open book tendering. The URE President has acknowledged that as a result of erroneous wording of the contested provision, this duty was not fulfilled through trading of electricity on Online Trading Platforms or in a regulated market. The Amendment Act has solved the problem by replacing an undefined entity - 'Online Trading Platform in Regulated Market' - with trading in a market organized by an entity operating a regulated market on the territory of Poland (see page 6).

A considerable number of provisions of the Energy Law Act was changed by the Amendment Act of 19 August 2011 including: Article 3; Article 7; Article 8(1); Article 9a); Article 91); Article 28(2); Article 32(1)(4)(b); Article 49a)(5)(3); Article 49a)(12); Article 54(1b); Article 56. New rules were added in the form of: Article 9e)(18)(4); Article 9p)(6) and (7); Article 9t)(15e); Article 23(2)(14a); Article 23(2)(19a): Article 54(1c). Finally, some provisions of the Energy Law Act were derogated such as Article 54(1a), for instance.

Redefined therewith was the term 'ultimate customer' (e.g. Article 3(13a) $\mathrm{PE})$. The current definition is more precise and states that energy consumed by an ultimate customer as part of 'personal use' should not include electricity bought in order to produce, transmit or distribute electricity. This change has eliminated any doubts about whether electricity bought for the production, transmission or distribution of liquid fuels, gas or heat should, or should not, be included into the category of personal use. By excluding the electricity used only for the production, transmission or distribution of electricity from the definition of 'an ultimate customer', the scope of the definition was narrowed down and the number of possibilities to avoid paying a transitory charge was limited.

The term 'agrarian biogas' constitutes another term that has been redefined (e.g. Article 3(20a) PE). Gas produced with raw materials provided by wastewater treatment plants and by landfills has been clearly and expressly

10 The Act on the Rules for Coverage of Producers' Costs Occurred Due to Premature Termination of Long-Term Contracts for Sale of Power and Electric Energy of 29/06/07 (Journal of Laws 2007 No. 130, item 905). 
excluded from the above definition. Change in the range of possibilities to obtain certificates of origin of agricultural biogas is a clear consequence of this Amendment Act. Another shift in definitions is visible in the replacement of the phase 'residues of agrarian and food industry' with 'residues from processing of agrarian origin products'. Defined as biogas can now be only gas derived from agrarian products and not than from by-products of agrarian and food processing (such as wastewater treatment by-products or fruit processing by-products). Change in the definition of the notion of 'agrarian biogas' makes it possible to classify plant processing residues intended for non-food purposes into the category of biogas.

The Amendment Act of 19 August 2011 defined also the notion of a market organized by an entity operating a regulated market in the territory of Poland as 'trading of commodities regulated by the Financial Instrument Trading Act of 29 July $2005^{11}$, by a company operating an exchange or by a company conducting off-exchange trade, respectively'. The introduction of a new definition into the Energy Law Act results from the changes in the scope of obligatory public trading of electricity. The new definition equates electricity trading in a market organized by an entity operating a regulated market in Poland with the fulfillment of the duty of public trading of electricity.

Subject to fundamental modification were provisions on the connection to the power grid (e.g. Article $7 \mathrm{PE}$ ).

Through the amendment of Article 7(8c) PE, the deadline for the payment of an advance towards power grid connection charges was extended from 7 days to 14 days. With respect to rules on the information duty of power transmission companies or power distribution companies (e.g. Article 7(81)(1) $\mathrm{PE})$, the range of information to be published by the said companies has been expanded. Added was a duty to publish information on 'the type of system' to be connected and on 'the value of the total available connection power' reduced by power resulting from released and valid statement of conditions. The frequency of data publication by entities applying for power grip connection and on available connection powers required from a transmission company or from a distribution company was lengthened from 'once a month' to 'once a quarter'. At the same time, the obligatory data posting on a message board at the registered office of an energy companies was replaced by the requirement to publish relevant information on a corporate homepage.

The duty imposed on a seller ex officio to buy electricity produced by renewable energy sources connected to the distribution grid or transmission grid on the territory where such seller carries out its operations, has been expanded through the inclusion of energy produced by biogas production

11 Journal of Laws 2010 No. 211, item 1384; 2011 No. 106, item 622 and No. 131, item 763. 
plants entered into the Register of Energy Producing Companies Involved in Production of Agrarian Biogas kept by the President of the Agricultural Market Agency (Article 9a(6) PE). This amendment has eliminated a manifest legislative error. As part of a promotional campaigns concerning agricultural biogases, the latter were exempt from stamp fees for official acts related to keeping the register of biogases (Article 9e)(18)(4) PE).

The most important change addressed directly by the Amendment Act of 19 August 2011 is the rewording of Article 49a) of the Energy Law Act which eliminated a legislative error which used to make public trading of electricity on Online Trading Platforms and in regulated markets impossible. At the same time, the legislator has eliminated the institution of an Online Trading Platform as one of the acceptable forms of public trading of electricity; other provisions applicable to Online Trading Platforms have been deleted including the power of the URE President to control platform access. It is worth noting that the notion of an Online Trading Platform was only introduced as a form of public trading of electricity as recently as March of 2010, under the Amendment Act the Energy Law Act and on Amendment to Some Other Acts of 8 January $2010^{12}$, and then was removed by The Amendment Act to the Energy Law Act and to Some Other Acts of 19 August 2011.

The possibility to trade electricity publicly in a regulated market was modified through the introduction of the institution of "market organized by an entity operating a regulated market on the territory of Poland' (Article 49a)(1) and (2) PE). Moreover, the URE President was given the right to review and to demand documentation and information important to the public trading of electricity (Article 28(2) PE). The lack of powers in this area used to make effective control impossible over the fulfillment of the duty by entities such as brokerage houses and merchandise exchanges.

Another remarkable amendment to the Energy Law Act introduced by the Act of 19 August 2011is the relinquishment - as matter of principle - of the duty to periodically verify registration and good standing (every 5 years). The duty to reexamine qualifications remains, nevertheless, which applies to those who have appropriate qualifications but have not been involved in the operation and maintenance of power facilities, systems or grids for a period of 5 years. In case of modernization or any other material change in the parameters of facilities, systems or grid, an employer of a person who is to operate them will have the possibility to apply for a verification of the employee's qualifications. The duty to verify qualifications every 5 years was also preserved in regard to those who operate facilities, systems, and grids that provide services to consumers as well as micro-, small-, and medium-sized

12 Journal of Laws 2010 No. 21, item 104.

VOL. 2012, 5(7) 
enterprises. Such recipients, should be able to carry out their operations in full trust of the qualifications and competence of those who act independently within the structure and system of energy companies; the latter being legally obliged to verify the adequacy of qualification possessed by those admitted to works related to the operation and maintenance of facilities, systems, and grids.

Amendments to the provisions on penalties imposed by the URE President (e.g. Article $56 \mathrm{PE}$ ) were intended to improve references in this provisions.

The aforementioned key changes brought about by the Amendment Act of 19 August 2011 caused also a number of minor modifications in the Energy Law Act (for example, rules on the concession procedure or the extent to which the URE President may settle disputes).

\section{Amendment Act to the Crude Oil, Oil Products, and Natural Gas Reserve Act and on the Rules of Procedure in Situations of Threat to National Energy Security and Crude Oil Market Disruptions and on Amendments to Some Other Acts of 16 September 2011}

The Amendment Act to the Crude Oil, Oil Products, and Natural Gas Reserve Act and on the Rules of Procedure in Situations of Threat to National Energy Security and Crude Oil Market Disruptions and on Amendments to Some Other Acts passed on 16 September 2011 had a relatively small impact on the content of the Energy Law Act. It constituted, however, an extensive amendment to the Act on Crude Oil, Oil Products, and Natural Gas Reserve Act and on the Rules of Procedure in Situations of Threat to National Energy Security and Crude Oil Market Disruptions of 16 February $2007^{13}$ ( hereafter, the Energy Security Act). The Amendment Act of 16 September 2011 modifies the system of obligatory reserves of natural gas in order to facilitate the entry onto the Polish market by new entities, which are interested in conducting business operations in the area of natural gas trading at an international scale and importation of natural gas, and to facilitate small scale operations carried out by existing market players. It was meant to create favorable conditions facilitating an increased number of business entities carrying out operations in the Polish natural gas market and by doing so, to increase competitiveness and improve consumer welfare through expected price cuts ${ }^{14}$.

13 Journal of Laws 2007 No. 52, item 343, as amended.

14 Source: Statement of Reasons for the Act on Amendments to Crude Oil, Oil Products, and Natural Gas Reserve Act and on the Rules of Procedure in the Situations of Threats to National Energy Security and Crude Oil Market Disruptions and on Amendments to Some Other Acts of 16 September 2011. 
The Amendment Act to the Energy Security Act changed the content of a number of provisions of the Energy Law Act: Article 33(1a); Article 35; Article 41(2a) and Article 43. All of these changes relate to the requirements that are to be satisfied by entrepreneurs who apply to the URE President for concessions required to trade natural gas internationally. The content of Article 33(1a) PE was made more precise, for instance, in stating the requirements to be met by those who apply for such concessions. Accordingly, the URE President is now competent to grant concessions for natural gas trading at international scale to an applicant who:

1 ) is in possession of its own storage facilities, or

2) has concluded a preliminary agreement for obligatory natural gas reserve storage services as referred to in Article 24(1) of the Energy Security Act of 16 February 2007, in an amount determined according to Article 25(2) thereof Act, or

3 ) has been exempted from the duty to keep obligatory reserves of natural gas referred to in Article 24(1) of the Energy Security Act.

Requirements related to the content of the application for a concession required to trade natural gas internationally were also changed. Apart from the general requirements listed in Article 35(1) of the Energy Law Act, an application for such concession should specify the forecasted amount of natural gas to be imported and the method employed to keep obligatory gas reserves on the territory of Poland, EU Member State or any EFTA Member State - parties to the EEA Agreement, according to the Energy Security Act. If applicable, such application should contain information on decisions issued by the Minister of Economy which exempt the applicant from the duty to keep obligatory gas reserves. A copy of such duty exemption decision must be enclosed (Article 35(1a) PE).

An applicant, starting its business operations exclusively in the area of natural gas exportation, is exempt from the duty to attach a notification of the Minister's of Economy decision exempting it from the duty to keep obligatory natural gas reserves if it is normally to be enclosed to the application for concession for trade on an international scale.

By force of the Amendment Act of 19 September 2011, a new obligation was enacted concerning the conditions of withdrawal of an international natural gas trading concession. According to Article 41(2a) of the Energy Law Act, the URE President shall withdraw such concession also in situations when an energy company involved in import of natural gas for resale to customers does not keep obligatory natural gas reserves or fails to provide accessibility of natural gas according to Article 24(1) and (2), Article 24a), Article 25(2) or (5) of the Energy Security Act.

Affected was also the legal institution of a promise issued by the URE President to grant a concession for international trading of natural gas. 
According to the new version of Article 43(6) of the Energy Law Act, the application for a promise of such concession should state the forecasted amount of natural gas to be imported and the method employed to keep obligatory reserves of natural gas on the territory of Poland, EU Member State or any EFTA Member State - parties to the EEA Agreement. Alternatively it should contain a statement that the given undertaking intends to apply to the Minister of Economy for an exemption decision from the duty to keep obligatory natural gas reserves.

It should be mentioned also that URE President's new powers and new responsibilities related to changes in the obligatory reserve system that are imposed, for example, on the Gas Transmission System Operator or on the Combined Gas Systems Operator, have not been included into the Energy Law Act. Instead, they have been incorporated into the amended Energy Security Act. They include, for instance, the duty to assess technical capabilities required to deliver all obligatory reserves to the gas system for a period of up to 40 days depending on the localization of such reserves.

\section{Jurisprudence}

This Section is dedicated to the overview of the most significant judgments delivered in 2011 by the Polish Supreme Court, Court of Appeals in Warsaw, and the Supreme Administrative Court concerning provisions of the Energy Law Act.

\section{Judgment of the Supreme Court of 6 October 2011 (Ref. No. III SK 18/11)}

The Supreme Court adjudicated in this ruling that a duty resulting from a concession in the meaning provided by Article 56(1)(12) of the Energy Law Act (sanction imposed for failure to fulfill duties arising from the concession) represents a duty stated in a given decision on the issue of a concession when such duty specifies operations to be carried out by an individual concessionaire under a given concession. The description in such decision must be more detailed and a more specific than it is required by relevant current legislation enforceable in a given field.

According to the linguistic interpretation of Article 56(1)(12) of the Energy Law Act, the behavior of an energy company consisting of the failure to fulfill duties resulting from its concession is an act punishable by a fine. The word 'resulting' means that something comes out as a conclusion of something else. 
Therefore, if failure to fulfill such duties resulting from a concession is the basis for the imposition of a fine under Article 56(1)(12) of the Energy Law Act, then the decision granting the concession must represent the autonomous source of the duties concerned.

A duty resulting directly from existing legislation that defines such duty in a way that makes its direct fulfillment possible, unless it is made more specific by a given concession, may not be treated as a duty resulting from the concession. Such duty does not result directly from the decision itself; instead, it results from an enactment (from a legislative act or from secondary legislation) governing the way in which operations covered by a given concession are to be carried out.

Seen as a duty resulting from a concession under Article 56(1)(12) of the Energy Law Act may be, however, a duty contained in a given concession if that decision specifies operations to be carried out by an individual concessionaire under a relevant concession, in more detail and in a more specific manner than it is required by relevant current legislation.

According to the views of the Supreme Court, Article 56(1)(12) of the Energy Law Act should be interpreted restrictively as referring merely to a breach by an energy company of special conditions under which it carries out its operations covered by its concession under Article 37(1)(5) of the Energy Law Act.

\section{Judgment of the Supreme Court of 30 September 2011 (Ref. No. III SK 10/11)}

The Supreme Court referred once again here to the issue of imposing fines on energy companies by the URE President. The Court stated that a strict liability nature must be associated with liability for the failure to fulfill duties resulting from the Energy Law Act sanctioned by a fine imposed by the URE President under Article 56(1). Therefore, the intentional or unintentional nature of misconduct does not have to be proven.

Nevertheless, this does not mean that there is no way to limit or even exclude liability. If a decision - taken by a regulator to impose a fine for the failure to fulfill duties resulting from the Energy Law Act or from a decision - is subject to an appeal, a higher level of judicial protection is provided to entrepreneurs for their rights. This rule makes it possible to modify the strict liability normally borne by energy companies.

The Supreme Court emphasized also that where a fine is imposed, the rules governing judicial verification of the accuracy of a penalty adjudicated by a public body should satisfy requirements corresponding to those to be met by a court that passes judgments in criminal cases. Therefore, a case, in which 
the URE President has decided to impose a fine on an energy company but the latter appealed such a decision, should be examined according to standards applicable to those charged in criminal proceedings.

An energy company may avoid a penalty if it manages to prove that the objective circumstances of a given case make it impossible to charge it with a breach of the Act because the energy company has taken appropriate preventive actions such as trading with a renowned supplier and acted according to parameters that conform to current standards (confirmed by an appropriate certificate).

\section{Judgment of the Court of Appeals in Warsaw of 28 September 2011 (Ref. No. VI Aca 139/11)}

The issue of imposing fines by the URE President on energy companies under Article 56(1) of the Energy Law Act was also assessed by the Court of Appeals in Warsaw. The Court stated that the extent to which a given act had an adverse impact on the environment did not constitute, by itself, a normative prerequisite for the imposition of a penalty under Article 56(6). According to this provision, the URE President takes, inter alia, the extent of environmental harm into account when he/she sets the amount of the fine to be imposed.

There is thus no ground for an obligatory determination of the extent of a detriment to the environment resulting from a given act of an energy company. If the circumstances of a particular case so require, the extent of environmental harm caused might be, however, taken into account within the proceedings carried out by the URE President.

\section{Judgment of the Supreme Administrative Court in Warsaw of 23 September 2011 (Ref. No. II OSK 667/11)}

The Supreme Administrative Court amassed in this case the issue of rights of an energy company set forth in Article 4 (general responsibilities of power grid companies as to the extent of services rendered by them) and in Article 7 of the Energy Law Act (power grid connection). The Court stated that rights of energy companies set forth in these two rules had to be exercised within the limits of current legal provisions and might not infringe the interest of real estate owners through which an energy company passes its infrastructure in order to supply its customers with electricity. 


\section{Judgment of the Supreme Court of 12 April 2011 (Ref. No. III SK 42/10)}

The Supreme Court considered here the settling of disputes between energy companies by the URE President (Article 8 PE). The Court was of the opinion that in regard to the powers of the regulator to settle a dispute concerning obligations (as a matter of principle, a civil law dispute) provided in Article 8 of the Energy Law Act, the said provision was an autonomous source of law even though its wording was abstract and terse. There is therefore no need to search for civil law structures (e.g. Article 64 of the Civil Code ${ }^{15}$ ).

A decision issued by the URE President under Article 8 of the Energy Law Act 'substitutes' a statement of intent of the parties (in the operational aspects of that notion) whereas, because of the legal nature of a regulatory decision, that decision constitutes the basis for the autonomous formation of legal relationship of those bound as far as the contagious issues between the parties are concerned.

\section{Judgment of the Supreme Court of 12 April 2011 (Ref. No. III SK 46/10)}

The Supreme Court referred to the tremendously important issue of limits within which a regulatory body may act. The dispute at hand concerned the fulfillment of a duty to purchase 'red' energy (i.e. electricity produced in highly efficient cogeneration) by energy companies (Article 9a)(8) PE). The scrutinized energy company failed to fulfill that duty properly and, as a result, was fined by the URE President. The energy company found, however, the fine to be disproportionately high.

The Supreme Court stated that a regulator was not allowed to impose such duties on companies subjected to regulation that they would lead to a situation where the company would be unable to avoid carrying out its operations at a loss. The Court emphasized also that liability for failure to fulfill duties resulting from the Energy Law Act is of the strict liability nature and a statement of intentional default is not necessary to impose a fine.

\section{Judgment of the Court of Appeals in Warsaw of 17 March 2011 (Ref. No. VI ACa 1027/10)}

The Court of Appeals in Warsaw ruled here on the limit of an energy company's duty to conclude an agreement for the connection to the power grid (Article 7(1) PE).

15 Journal of Laws 1964 No. 16, item 93. 
The Court of Appeals clarified that Article 7(1) of the Energy Law Act clearly provided that an energy company involved in the transmission or distribution of electricity was obliged to conclude a power grid connection agreement with businesses applying for such connection (with each of the entities applying for connection individually, not only with a customer). The duty of energy companies resulting from Article 7(1) applicable to entities applying for a power grid connection is not limited to customers but is also imposable on the producers of electricity.

\section{Summary}

The review of legislative and juridical developments in the Polish Energy sector in 2011 leads to the conclusion that the aforementioned amendments and changes did not have a revolutionary nature. They exercised, nevertheless, an unquestionable impact on the shape and operation of the national energy market.

It should be kept in mind that the shape of the 2011 amendments to the existing Energy Law Act of 1997 was influenced by the need to pass a fundamentally new Act on Energy Law. Indeed, amendments to the current Act have long since taken the form of ad hoc modifications rather than long-term solutions. Works are currently under way to enact as fast as possible a 'threefold' legislative package encompassing three new acts that would comprehensively regulate the Polish energy market (understood in the broadest sense of that term) - a new Energy Law Act, a new Gas Law Act, and a new Renewable Energy Source Act. 